\title{
A Different Kind of Archival Security: Three Cases
}

Richard J. Cox, Abigail Middleton, Rachel Grove Rohrbaugh, and Daniel Scholzen

Introduction. When archivists and other records professionals have considered the matter of security, they have generally thought of protection of their holdings, measures to thwart insider theft, and other approaches to ensure that the records they have responsibility for can be used and maintained in ways that guarantee careful control and preservation. Such issues bring to mind security cameras, locks and other protection devices, special staff training, carefully prepared policies and procedures, and security consultants.

There is another kind of archival security, however, where efforts are made to make sure that documents created by individuals and institutions, especially those with some connection to controversial or contentious events, survive to be used in the future. This aspect of archival security involves accountability and ethics, topics growing in importance in the archival community (and, it seems, in all of the information professions). Matters of accountability and ethics have become more than hypothetical issues for working archivists. Increasingly, archivists are confronting issues relating to access, ownership, and public policy that challenge traditional attitudes and practices. These three cases - the ownership and control of the records of indigenous peoples, the use of government records created as part of the normal procedures of the Supreme Court, and the misadministration of electronic mail messages generated by the White House - provide some illuminating lessons about the kinds of contentious issues archivists will increasingly face. All of them, if improperly handled, threaten to eliminate, damage, or weaken the documentary heritage for future generations - that is, 
threaten the security of what constitutes our documentary heritage. While there may seem to be pronounced differences between the claims of indigenous peoples in wanting greater respect for their cultural heritage and issues concerning access to or the management of government records, all these cases pose substantial threats to how archival sources are protected and the well-being of communities in regard to their collective memory.

The purpose of this essay is to confirm that the notion of archival security that needs to be considered in the future is best demonstrated through case studies, ones either suggesting the need for additional research and reflection or opening up the horizon to reveal practical solutions. Each of the cases described here suggest disturbing barriers for archivists and their allies to ensure that there will be a documentary heritage in the future. After these cases have been presented a brief set of lessons or themes will be discussed.

Diminishing Access, or Archival Insecurity. In a manner, what we are considering here is the ethics of access, a topic that has been a regular, some might say prominent, topic in the professional literature in the past two decades or more. Just about two decades ago, Elena Danielson commenced her essay on the ethics of access in this way: "Providing fair access to archives may appear to be a fundamentally simple operation, until one examines specific cases."1 At that point in time, the cases she could mention included the Francis Lowenheim charges against the staff of the Franklin D. Roosevelt Presidential Library concerning the alleged withholding of documents, the use of Sigmund Freud papers held by the Library of Congress and controlled by his estate, the ownership of the Richard Nixon tapes and other presidential records, and so forth. 
Just as Danielson was retelling and reinterpreting the particulars of these wellknown cases, new cases were appearing. Another case study about the Carl and Anne Braden papers at the State Historical Society of Wisconsin was published. A few years earlier the FBI sought to gain access to these papers to defend itself against a lawsuit brought by an organization that Anne Braden belonged to; the Braden papers only could be used with the permission of the donors, and Anne Braden (her husband had died the decade before) refused to grant access. The FBI subpoenaed the files. According to Harold Miller, this was an "unprecedented" case: "While courts had been asked to pen restricted public records, they had never before been asked to order access to private papers in the hands of an archival repository." ${ }^{2}$ The Wisconsin archivists, even with their lack of success in persuading the Society of American Archivists to join with them in an amicus brief prepared by the Center for Law in the Public Interest, sought to establish the legal precedent of "archival privilege" (like the lawyer-client privilege, but in this instance between a donor and an archival repository). ${ }^{3}$ Ultimately, the state historical society lost its case, leading to some sobering conclusions about how effectively any donated collections could be protected: "Once in an archives the general content of a collection, even when restricted, generally becomes public knowledge. The collection thus becomes more likely to be subpoenaed." ${ }^{4}$

By the mid-1990s, enough troublesome cases about archival access had developed that some questioned anything they read in basic archival manuals. Mark Greene, for example, opined in 1993 that "To do as the manuals say, and to have the repository take on the responsibility of determining what should be restricted, is to place what would seem to be an impossible burden on repository staff - that of determining just what 
material does or does not constitute an invasion of privacy or breaches the confidentiality of business information across thousands of collections, hundreds of thousands of folders, and tens of millions of documents." ${ }^{, 5}$ If matters seemed impossible in 1993, the situation might appear even worse today, as intellectual property challenges have become far more complicated. Proprietary control measures, government secrecy, and the porous nature of information systems all seem poised to conspire against ensuring the viability of a documentary heritage in the future.

More cases continued to appear reflecting the immensity of the challenges facing archivists, seeming to conspire to form a new archival insecurity. Jodi Allison-Bunnell, for example, explored the complicated circumstances of the ownership of the Katherine Anne Porter papers at the University of Maryland, all the more problematic since the intellectual property rights seemed even to interfere with the efforts to microfilm the papers in order to provide more sensible protection of the fragile originals. AllisonBunnell notes that the various court cases "have made literary manuscripts curators extremely cautious about providing additional access to the letters of correspondents contained in their collections." ${ }^{6}$ Not long after that, another case study, this one concerning the access to the Mississippi State Sovereignty Commission records, further emphasized the growing complications of the archival world. This state agency, existing from 1956 to 1973 , compiled records on 87,000 people suspected to be supporting the civil rights movement in that period. Like other secret police files, archivists administering these records faced heavy problems regarding the implications to innocent people in opening the files. Lisa Speer notes, "Regardless of the context of the commission files, the controversy surrounding their disposition illustrates the heavy 
responsibility faced by the courts and the archival community of balancing individual privacy rights against the public interest."7 In this particular instance, Speer suggests that this controversy is a "perfect case study of the complexity involved in balancing access versus privacy rights with regard to public records."

\section{Case One. The Ethics of Archiving Native American Collections: A Look at the}

Protocols for Native American Archival Materials. In the United States, legislative acts protecting antiquities and preserving cultural heritage date back to the early twentieth century with the passage of the American Antiquities Act of 1906. Despite this act, the history of collecting, preserving, and displaying artifacts from the Native American tribes has a less than ethical past. In the early days of "smash and grab" archaeology, the rights and considerations of those being exploited were of little concern. The social sciences "were conceived in sin: ethics demands that we treat people as subjects; social science requires that we view them as objects."9 Throughout the twentieth century, other such acts protecting Native American burials and archaeological sites were passed, but the Native American Graves Protection and Repatriation Act (NAGPRA) of 1990 is the most significant. NAGPRA finally gives these "objects" of study a voice and control of their cultural heritage. ${ }^{10}$

The history of legislation combating mistreatment and misrepresentation of Native American objects has made great strides toward protecting and preserving Native American cultural heritage. Yet all of this legislation fails to address the care and handling of culturally sensitive material held in archives and libraries throughout the country. Documents, moving and still images, transcripts, and sound recordings 
depicting culturally sensitive subjects do not fall under the jurisdiction of NAGPRA. The Protocols for Native American Archival Materials were drafted to "identify best professional practices for culturally responsive care and use of American Indian archival material held by non-tribal organizations." ${ }^{11}$ What are the ethical considerations of archiving culturally sensitive material relating to Native Americans and the way in which the Protocols address these ethical challenges?

NAGPRA requires federal institutions that receive funding from the federal government to return sacred objects to the Native American group to whom they belong. This includes sacred funerary objects, human remains, and other items with significant cultural value. Under NAGPRA legislation, museums and cultural institutions are required to inventory their holdings and submit a summary to a NAGPRA Review Committee. ${ }^{12}$ These institutions must then return, or repatriate, the artifacts to the culturally affiliated Native American tribes. NAGPRA also outlaws the trafficking of human remains and funerary objects. ${ }^{13}$

While nearly two decades of NAGPRA have seen the repatriation of cultural items from across the country, culturally sensitive materials remain in libraries and archives across America. Examples of this culturally sensitive material include still and moving images of human remains, religious and sacred objects, ceremonies, burials and funerals as well as recordings or transcripts of songs or chants, religious or healing practices, and personal or family information. Maps of sacred or religious sites and other documentation relating to archaeological data of Native American sites are also considered culturally sensitive. ${ }^{14}$ 
The ethical issues concerned with holding this material and making it available to anyone to see and use are numerous. Even among the Native American communities, not all of this information would be available for all of the tribe members to see and use and "for Native American communities the public release of or access to specialized information or knowledge-gathered with and without informed consent-can cause irreparable harm." ${ }^{15}$ It is not uncommon that this culturally sensitive material was gathered without the informed consent of the tribe members or individuals, making exploitation of individuals and their knowledge a serious concern. Finally, the perceptions about Native American culture by often non-native archivists may skew the historical picture of Native American history, often taking material out of context. ${ }^{16}$

In an attempt to address these ethical concerns and create a dialogue between communities as well as guidelines for the proper care and handling of culturally sensitive material, a group of nineteen Native American and non-Native American archivists, librarians, historians, anthropologists, and museum curators recently drafted the Protocols for Native American Archival Materials. The group gathered at Northern Arizona University in April 2006 tasked with the mission, and the Protocols were the result of that meeting. The Protocols address: "The recognition of the sovereign governments and associated rights of Native American communities; issues in the collection, ownership, preservation, handling, access, and use of American Indian archival resources; the importance of building relationships, balancing different approaches to knowledge management, and mutual respect; the need to expand the nature of the information professions to include Native American perspectives and knowledge."17 
These Protocols are unprecedented in the archival and library communities and are a show of willingness on the part of the information community to adopt an alternative approach to archives as a means of honoring the traditions and values of others. ${ }^{18}$ This ethical self-awareness has been recognized and indorsed by institutions and organizations in a variety of disciplines. The Protocols themselves are based on the laws, ethical codes, and international declarations of twelve organizations, including the American Anthropological Association, the Society of American Archivists, the American Library Association, and the American Association for State and Local History. ${ }^{19}$

The Protocols address ten areas of concern for dealing ethically with culturally sensitive material in archives and offer guidelines for action for archivists and librarians as well as for Native American communities. The Protocols present a real challenge to archivists and librarians as they call into question many of the ways in which archivists administer their collections. The ten Protocols are

Building Relationships of Mutual Respect

Striving for Balance in Content and Perspectives

Accessibility and Use

Culturally Sensitive Materials

Providing Context

Native American Intellectual Property Issues

Copying and Repatriation of Records to Native American Communities

Native American Research Protocols

Reciprocal Education and Training 
Awareness of Native American Communities and Issues. ${ }^{20}$

While all of the Protocols address issues of ethical concern for managing Native American archival material, three of the protocols representing the greatest ethical challenges will be discussed.

Accessibility and Use. Accessibility and use can present one of the greatest challenges for researchers using archival collections. It is the charge of the archivist or librarian to provide access to the collections. The "archivist must mediate between offering 'supportive collegiality' to researchers and operating within the legal and ethical boundaries established by donors and the contents of literary papers."21 This protocol challenges the archivist further by requesting archivists honor access and use restrictions requested by tribes and "recognize that the conditions under which knowledge can be ethically and legally acquired, archived, preserved, accessed, published, or otherwise used change through time. Some materials may have been collected or later restricted by a donor in contravention of community rights and laws or of contemporary federal laws or professional ethics. In all of these cases the rights of a Native American community must take precedence." ${ }^{, 2}$ If the Native American community deems unrestricted material culturally sensitive, it will be the decision of the archivist to determine whether it is his or her ethical obligation to restrict the material. Archivists and librarians taught to champion open access and intellectual freedom to resources may be troubled by the idea that in Native American communities knowledge can be collectively owned. Access to some knowledge may be restricted as a privilege rather than a right. ${ }^{23}$

Culturally Sensitive Materials. The National Historic Preservation Act allows federal agencies to withhold information about the location of religious and historically 
significant sites, but far more culturally sensitive materials are held in archives and available to the public than what this act protects. ${ }^{24}$ This material in archives is a particular ethical concern because to a non-Native archivist, much of this material may not be seen as sensitive in nature. Archivists must understand the importance to Native American communities of protecting this sacred material from exploitation and misuse. Though definitions of culturally sensitive material will vary from group to group, the Protocols provide examples to guide archivists and librarians in identifying this material.

Providing Context. It is easy to see the culturally responsive course of history in a library catalog. Derogatory terms and other outdated word usages often remain, though frequently with references to the more accepted term. This protocol takes into consideration original language and tasks the archivist with adding the explanations of derogatory words to original titles, removing offensive terms from original titles, and providing substitute words for the offensive terms. Our vocabulary has grown and changed along with our cultural awareness and sense of understanding. Maintaining these words, that many find offensive, is degrading. From an ethical standpoint, archivists at the very least should acknowledge the derogatory nature of the words and provide alternatives.

This protocol also calls for supplemental descriptive materials to accompany culturally sensitive material informing researchers of concerns in the community and of the existence of research protocols if there are any. With these statements, the users are well informed of the sensitive nature of the material from the beginning and are obliged to treat it with care and respect. 
Ultimately, adopting the Protocols means much more work for the institution holding the material, so it is necessary to examine why the Protocols should be adopted. First, the types of culturally sensitive material held by archives and libraries will differ from place to place, and the tribal guidelines dictating the handling of this material will also differ. ${ }^{25}$ The Protocols provide a basic outline for establishing a dialogue and creating a cooperative effort to ensure the proper care and handling of the material. Though the guidelines may not be tribe-specific, they raise the concerns of the Native American community and create awareness among the archivists and users.

Some believe that restricting access to research material for reasons of cultural sensitivity is shortsighted, political, and anti-intellectual. ${ }^{26}$ The Protocols attempt to combat this by building relationships with the Native American community and the holding institution. ${ }^{27}$ The Protocols do not seek to restrict all access to culturally sensitive materials, but, rather, they primarily seek their identification and respectful treatment. The cooperative spirit of the Protocols allows Native American consultants to help identify this material and take the necessary steps to ensure it is protected and used in the proper context.

The affect the Protocols for Native American Archival Materials will have on the archival, library, and Native American community is yet to been seen. It is important to note that unlike NAGPRA, the Protocols are not a legislative mandate but are simply guidelines for identifying and adopting best professional and ethical practices for "culturally responsive care and use" of Native American archival materials. ${ }^{28}$ Because of the voluntary nature of the Protocols, predicting the implementation and use of them is difficult. 
Similar protocols were adopted by the Australian organization the Aboriginal and Torres Strait Islander Library Information and Resource Network (ATSILIRN). The Aboriginal and Torres Strait Islander Protocols for Libraries, Archives and Information Services were published in 1995 . The impact of these protocols nearly thirteen years later is still uncertain. According to the ATSILIRN website, "after a decade in circulation, it was recognized that there is little in the research literature that identifies the extent of the use of the Protocols, or their value and effectiveness in workplaces across the LIS sector." ${ }^{29}$ The ATSILIRN Protocols were updated in 2005, and they reflect many of the same ethical concerns as the Native American Protocols.

While the Native American Archives Roundtable of the Society of American Archivists (SAA) has endorsed the Protocols for Native American Archival Materials, the SAA at large has not endorsed the Protocols. The Protocols were presented for endorsement to the SAA Council at it's late summer meeting in 2007. After calling for public comment on the Protocols in late 2007, the SAA created a Task Force to "review and summarize (without recommendations for action) the comments received." ${ }^{30}$ The Task Force will submit a report with recommendations regarding the next steps the Council should take in considering the endorsement of the Protocols.

While it is uncertain what impact an SAA endorsement will have on the implementation of the Protocols, all cultural institutions holding Native American material and culturally sensitive archival collections should endorse the Protocols. Institutions holding these materials should use the Protocols as a means of ethical selfevaluation and to establish a dialogue with Native American communities. Adopting the Protocols does not mean that institutions will have to restrict access to their collections or 
repatriate culturally sensitive material. Adoption of the Protocols is an indication that the institution is taking a pro-active approach to fulfilling its moral and ethical obligations to the both Native and non-Native communities.

Case Two. The National Archives and the Supreme Court Tapes Controversy. During the course of his remarks at the 2003 conference Political Pressure and the Archival Record, Verne Harris commented, as he so frequently does, on the inherent politics of recordkeeping and the constant need for awareness and activism. His words are worth revisiting here: "Activists need to be wary of the penchant for those who hold power in democracies to hold up contract as a substitute for contest. Sometimes the powerful go so far as to suggest that contestation unravels the contract. These, I want to suggest are subterfuges, strategies for entrenching power. It is to confuse law, and right, with justice."31 While Harris's remarks are influenced by his own experiences as a "contestant" in South Africa, they are also informed by the notion that too often archivists stand as defenders of the "contract" and in turn the interests of those in power. Quoting Bob Dylan, Harris argues that these individuals are "trained to take what looks like the easy way out."32

This case study is unfortunately an all too perfect example of archivists who bowed to the will of the powerful and literally upheld "contract" in the face of "contest." A discussion of the events related to Peter Irons' public release of tapes of the U.S. Supreme Court's oral arguments should clarify the particular need for ethics and transparency in government archives as well as the need for more archivists who are not afraid to speak out. Today, in 2008, anyone interested in reading a Supreme Court opinion or listening to a digital recording of the Court's oral arguments is confronted with 
a wide variety of options, from commonly available databases such as Lexis-Nexis to free websites like Oyez and Findlaw. CDs and book length transcripts can be found in most libraries and large bookstores. Archivists had little to do with this turn of events.

Yet as recently as the early 1990s, Supreme Court materials were hardly easy to obtain. Opinions could only be accessed at law libraries or through expensive commercial providers. Oral arguments were even harder to come by, distributed by one authorized company on a pay per view basis. ${ }^{33}$ The individual justices who spoke were not even identified in these transcripts. ${ }^{34}$ Video cameras were, as they still are, certainly not permitted, and due to space limitations, even those who traveled to Washington and stood in line outside the courtroom rarely got to listen in for more than a few minutes before giving up their seat to the next person in line..$^{35}$

Few people knew that since October of 1955 the Supreme Court had been recording its proceedings for internal use and depositing these tapes in the National Archives. Up until 1986, any researcher was free to request copies from the master reels and use them without restriction. This policy changed, however, after Fred Graham of CBS News broadcast portions of the Pentagon Papers case on radio and television for the case's fifteenth anniversary. ${ }^{36}$ Then Chief Justice Warren Burger was furious and demanded that the FBI investigate how Graham had obtained the recordings. When Burger realized they were freely available at the National Archives, he convinced Archives staff to limit access to only those who agreed to sign a statement that they would use the tapes "for private research and teaching purposes only."

No one seemingly defied Burger's wishes until political science professor Peter Irons visited the National Archives around 1991. As the director of the Earl Warren Bill 
of Rights project at the University of California, San Diego, Irons was looking for innovative teaching materials that would readily resonate with students. After the publication of his 1988 book, The Courage of Their Convictions, which is based on interviews with individuals involved in Bill of Rights cases argued before the Supreme Court, the professor was overwhelmed with positive responses from teachers and students, who praised the book's first-person accounts..$^{38}$ Irons wanted to produce something that would "bring the Bill of Rights to life" in much the same way ${ }^{39}$ and he recalled the experience of listening to the 1958 case, Kent v. Dulles, in an appellate advocacy class at Harvard Law School in $1978 .{ }^{40}$ Recognizing their educational potential, Irons sought out the Supreme Court tapes at the National Archives with the intention of editing them and adding commentary for widespread classroom use.

Before he arrived at the National Archives and was asked to sign the agreement, Irons had no knowledge of the restrictions on the tapes. "I considered [the restrictions] unenforceable and a violation of the First Amendment," Irons later remarked. "These were public records, not classified or subject to the Privacy Act.” He considered suing the Archives on First Amendment grounds, but decided instead to take his chances, sign the restrictions agreement, and proceed with his plans to market the tapes. ${ }^{41}$

Still, in an attempt to gain the Court's approval, Irons sent copies of the edited tapes to several current and former members. Then Chief Justice William Rehnquist's administrative assistant, Robb Jones, responded in a letter on the justice's behalf, giving his consent and hearty approval. Jones wrote, "I applaud the concept and your efforts. I know [the tapes] will contribute to educators' and the public's understanding of the Court's role and the function of oral arguments., ${ }^{, 2}$ Emboldened, Irons made 
arrangements with a non-profit publisher to distribute excerpts from 23 landmark cases such as Miranda v. Arizona and Roe v. Wade in a book and on audio cassettes.

May It Please the Court was first published in August of 1993 to the Supreme Court's immediate and extremely public disapproval. In a quick reversal on Jones's earlier letter to Irons, the Court's public information officer released a statement pointing to the agreement the professor signed at the National Archives. Toni House, Supreme Court press officer, followed up with a threat of legal action: "In light of these clear violations of Professor Irons' contractual commitments, the Court is considering what legal remedies may be appropriate."43

Press coverage over the next few weeks predominantly favored the wide release of the tapes, if not always Peter Irons himself. Former Solicitor General, Charles P. Fried, charged Irons with "gross dishonesty" for his violation of the Archives' restrictions ${ }^{44}$ and a New York Times editorial observed misidentifications in the May It Please the Court transcripts and accused Irons and his co-editor, Stephanie Guitton, of "sloppy work and dubious judgment." ${ }^{45}$ Nevertheless, most commentators focused on the weaknesses of the agreement Irons signed and criticized the Court's demands for secrecy. A Washington Post editorial noted that the recordings and transcripts are in the public domain and likened them to Congressional records: "[The material] was produced by the government, using taxpayer funds, on government time, and it should be available to the public. ${ }^{46}$ William Safire of The New York Times colorfully expressed the same sentiment: "Public officials with their heads in the $19^{\text {th }}$ century think they can keep public records from commercial exploitation by limiting their use to 'scholarly research.' That's like being a little bit pregnant; as the Dead Sea Scroll monopolists learned, ${ }^{47}$ 
unless a public document or tape or photo is a national secret or an invasion of privacy, it should be and will be available for dissemination in any way the market system decides. Tapes -- yesterday audio, tomorrow video -- of open Court argument are the public's property, not the personal trusts of the justices. If I want to photograph the Declaration of Independence and sell it on a t-shirt, that's my business, not the National Archives's." ${ }^{48}$

Faced with this sharp and logical criticism, the National Archives failed at this point to make any appropriate, public response. On September $24^{\text {th }}$, The Washington Post reported that the Court's marshal, Alfred Wong, had told Acting Archivist of the United States Trudy H. Peterson in a recent letter to not give Peter Irons anymore copies of the tapes without the permission of the Court. Cited in the same story, an Archives spokeswoman acknowledges that as a caretaker of the Court's documents, the National Archives will follow Wong's instructions. ${ }^{49}$ The National Archives said nothing more officially until the Court yielded to press scrutiny on November $1^{\text {st }}$ and requested the removal of all restrictions on the tapes..$^{50}$

Peter Irons went on to produce three more May It Please the Court sets on the issues of abortion, the First Amendment, and education respectively. ${ }^{51}$ The Supreme Court has adapted somewhat over the years and now posts transcripts and recordings to its own official website and even issued an audio broadcast of the oral arguments in Bush v. Gore to be played on radio and television. Still, the judiciary remains the most secretive and least understood branch of the federal government, ${ }^{52}$ and in the fifteen years since the Peter Irons tapes controversy, no one in the archival community has really discussed the appalling actions (or non-actions rather) of the National Archives in this case. 
In his testimony to a 2005 Senate hearing on the use of video cameras in the courtroom, Peter Irons maintained that the Archives staff initially opposed Warren Burger's demand for restrictions in 1986 but conceded when the chief justice threatened to withhold all future tapes. ${ }^{53}$ One might imagine that a similar threat motivated the National Archives in 1993 or simply a more generalized fear of alienating the Court. Perhaps the Archives resisted the idea of suddenly backing down on a restrictions agreement they had so recently been upholding without objection.

Yet as William Safire contended with his allusions to the Dead Sea Scrolls and Declaration of Independence t-shirts, the problem with all this is that the tapes were, of course, public records. Anyone should have been able use them without restriction for purposes educational, commercial, or otherwise. The Supreme Court is a governmental body, not a private donor whose wishes and privacy must be taken into account. ${ }^{54}$ The National Archives' decision to follow the Court's directives and fail to defend the public's right to know flies in the face of the ethical standards of the archival profession. ${ }^{55}$ Singling out Peter Irons and not allowing him alone to make copies of the tapes without the permission of the Court is an indisputable example of unequal access.

The National Archives' deference to the Supreme Court stands in stark contrast to the Library of Congress's dealings with the Court earlier that year in a remarkably similar case. When former justice Thurgood Marshall died in January of 1993, less than two years after leaving the bench, his personal papers were immediately opened to researchers at the Library according to the terms of his deed of gift. On May $24^{\text {th }}$, The Washington Post published two articles, which heavily drew upon Marshall's papers, and in the days that followed, the Library of Congress was attacked from all sides. 
Marshall's family, friends, former clerks, and colleagues voiced their opinion that Marshall would have never wanted his papers opened so soon. They also questioned the Library's decision to allow journalists to access the papers, noting that the deed of gift specified that they were to be used "by scholars or researchers engaged in serious research. ${ }^{{ }^{56}}$ On May $26^{\text {th }}$, William Rehnquist sent an open letter to Librarian of Congress James H. Billington and claimed to speak for a majority of the Court's current members. In the letter, Rehnquist boldly suggests that the Library should have consulted with the Supreme Court before opening the papers "given the Court's long tradition of confidentiality in its deliberations" and declares that "future donors of judicial papers will be inclined to look elsewhere for a repository." ${ }^{57}$

Despite the attacks from individuals as prominent as Rehnquist, the Librarian of Congress refused to back down, defending his position that Marshall fully understood his agreement with the Library and that all adults, including journalists, can be engaged in serious research. He arranged meetings with Rehnquist and the Marshall family to explain the language and circumstances of the donor agreement ${ }^{58}$ and released a detailed statement to the press. In the statement, Billington expresses his sympathy with all parties involved but insists that any attempt to limit access "is a breach of contract and a violation of the trust placed in the Library by the donor." ${ }^{, 59}$ The library community rallied behind Billington. The editor of Library Journal published an editorial commending the Library of Congress and any efforts to encourage open government,${ }^{60}$ and the ALA passed a resolution on June $30^{\text {th }}$ supporting access to the Marshall papers and the notion that journalistic research is serious research. ${ }^{61}$ 
The Library of Congress's reaction to criticism over the Marshall papers is a model for how the National Archives should have responded to the Supreme Court's requests for restrictions on the oral argument recordings. In cases such as these (the Marshall papers, the Dead Sea Scrolls) the archivist or librarian's best bet is to take the case to the press. The absurdity of overzealous restrictions can rarely withstand public scrutiny (or so we can only hope). As Richard Cox and David Wallace observe in their introduction to the collection Archives and the Public Good,

Archivists and records managers need to move well beyond their traditional notion of advocacy in which the public and policymakers gain an appreciation for archives and records to making them understand and support the essential reason that records are created, how they need to be maintained, and what makes them significant. $^{62}$

In other words, archivists have a duty to educate the public wholeheartedly and stand up for ethics and transparency in recordkeeping. This is the only way they will build trust in the work they do. Archivists certainly cannot expect all their researchers to be like Peter Irons and to speak out for them on issues of accountability.

In both the Irons and Marshall cases, the actual records and documents showed the Supreme Court in a remarkably favorable light, as dedicated individuals who comprehend the serious and far-reaching repercussions of their decisions. If the National Archives was not able to withstand the Court's pressure on relatively positive and clearly public materials, how can we expect this institution to speak out on more controversial or even classified documentation? This worry is compounded today by the excessive 
secrecy of the post-9/11 political environment, an environment in which whistleblowers face the continuing threat of retribution.

In his 2007 book Nation of Secrets, Ted Gup compares information to water. "Secrecy," Gup writes,"...arrests the natural flow of information. Like water, even vast amounts of information can be restrained. But over time, its impoundment erodes democracy and ultimately threatens it with collapse."63 Archivists, librarians, and records managers, particularly those working within the government, should be prepared to ease, not hinder, this "natural flow of information," even if it means taking risks and standing up to the powerful. As Verne Harris has said, "I refuse to turn my back on higher callings, and I encourage everyone in archives to make the same refusal...we are guaranteed the self-respect that comes from a refusal to seek the easy way out." ${ }^{\circ 4}$ Case Three. The Archival Response to the "Lost" White House E-Mail. For obvious reasons, the importance of records is a major theme within archival literature. Selection, appraisal, organization, and preservation of documentary material are common topics of discussion among both archivists and records managers. The need to provide access to records is also clearly recognized within professional discourse. Indeed, the emphasis placed upon access and related issues only serves to underscore a rhetorical commitment to freedom of information and government accountability.

Nevertheless, as of this writing, the archival profession has been largely silent regarding the mysterious disappearance of e-mail generated by the Bush administration. This is, in some ways, not a great surprise. For although deliberate destruction of material by corporate or government actors is universally denounced by archivists, relatively little substantive action has historically resulted on the part of the profession in response to 
specific examples of malfeasance. To be sure, a few individual archivists are speaking out against the Bush administration. ${ }^{65}$ However, because the material involved in the White House e-mail scandal is clearly protected by federal legislation, and considering the potentially devastating impact of such an erasure on the historical record, the passivity on the part of the archival profession as a whole is extremely troubling.

While archivists have generally proven quick to recognize real or perceived threats to professional interests, they have often been slow to act to in defense of core values, as can be seen in the case of the missing White House e-mail. Although the destruction or suppression of Bush White House e-mail might initially appear to be a distinct problem, it is, on the contrary, inextricably intertwined with other contemporary controversies. Knowledge of the missing e-mail first emerged during an investigation into whether the Bush administration deliberately exposed the identity of a covert CIA officer ${ }^{66}$ While the White House has consistently denied accusations of deliberate destruction, certain patterns are clearly evident. For instance, extended periods of missing e-mail just happen to coincide with the invasion of Iraq and Hurricane Katrina, two of the more notable disasters of the Bush era ${ }^{67}$ E-mail has also been lost for dates when the White House was subject to court orders to either preserve or turn over such documents. ${ }^{68}$

Of particular significance for the archivist, by using non-government e-mail accounts the Bush administration deliberately and systematically evaded restrictions established by the Presidential Records Act (PRA). ${ }^{69}$ The existence of a parallel e-mail system funded by the Republican National Committee (RNC) and regularly used by many top White House staff was first revealed by Congress in April 2007. ${ }^{70}$ Knowledge of the existence of a parallel e-mail system that was regularly used by certain White 
House staff was first acknowledged by Congress in April 2007. Despite evidence to the contrary, the Bush administration initially claimed that it did not use e-mail accounts and equipment provided by the Republican National Committee (RNC) in an official government capacity. ${ }^{71}$ The White House further insisted that it did not consider this "electronic back channel" "ᄁ2 as a means to disguise political activity. However, the Justice Department was eventually forced to turn over evidence that, despite its prior protestations, the Bush administration had used the RNC e-mail accounts during discussion of the firing of a group of U.S. Attorney's General. ${ }^{73}$ The White House initially failed to turn over such records, claiming that they had either not been properly archived by the e-mail software or simply failed to turn up during routine searches. ${ }^{74}$ White House staff members were almost certainly aware that the RNC was not in the habit of preserving e-mail sent through its servers. ${ }^{75}$

Alarmed by White House behavior, the House Oversight and Government Affairs Committee eventually expanded its investigation. ${ }^{76}$ By mid-April 2007, the White House was forced to acknowledge that at least five million e-mails from its own system had been either lost or destroyed. ${ }^{77}$ Even in the face of widespread skepticism, the Bush administration has consistently blamed technical glitches or archiving anomalies for the huge volume of missing e-mail. ${ }^{78}$ The White House has, for instance, often claimed that the e-mails were lost during a conversion from Lotus Notes to Microsoft Outlook which was completed in $2003 .^{79}$

Even more problematic, the White House claimed that it recycled and reused email backup tapes until late 2003, in the process likely destroying many records created prior to that time. ${ }^{80}$ From a technical standpoint, the practice of recording over backup 
tapes makes little sense because such media is too inexpensive for recycling to be feasible. ${ }^{81}$ In any case, the backup tapes used by the White House did not capture all email sent and were not considered reliable or sufficient for meeting federal records laws. $^{82}$

Although the White House claims it had stopped recycling tapes by October 2003, e-mail created after that time has also disappeared. ${ }^{83}$ Indeed, for some dates no e-mails sent by White House staff have been preserved at all. ${ }^{84}$ At one point, as many as 473 separate days with at least some missing e-mail were identified. ${ }^{85}$ This is difficult to comprehend since the White House logs up to 100,000 e-mails per day, all of which are required to be preserved by either the PRA or the Federal Records Act (FRA) ${ }^{86}$ By late February 2008, the estimated number of days with missing e-mail had been reduced to 202, a significant decrease but still an astonishing number. ${ }^{87}$ The problem appears to be widespread within the Bush administration. The Office of the Vice President, for example, lost some of its e-mail from $2003-2005,{ }^{88}$ and other digital records may have similarly gone missing. ${ }^{89}$

As of February 2008, the Bush White House still did not have an archival quality records-management system in place to organize and retain electronic communications..$^{90}$ For some time, in fact, the Bush administration continued to rely upon a program requiring e-mail to be manually copied, saved, and stored. ${ }^{91}$ Such a system, apart from being decidedly archaic, is acutely vulnerable to manipulation or abuse. Indeed, until at least mid-2005 anyone using the White House network could easily access, modify, or delete e-mail. ${ }^{92}$ 
Although no indisputable evidence of illegal action has so far been uncovered, the e-mail scandal, as some have noted, contains at least "a whiff of Watergate." $" 93$ Due to what can only be described as negligence, incompetence, or deceit, millions of records documenting the most controversial events of the last eight years may be lost forever. The resistance of the Bush administration is only compounded by the fact that in late February 2008 the RNC announced, without further explanation, that it had ceased searching for White House e-mail on its servers and had no plans to perform any future work. $^{94}$

While the White House e-mail scandal has received its share of attention in the press, relatively little public outrage has been evident. This might be explained by the fact that the story has been gradually unfolding over a long period of time and has never reached any sort of critical political mass. Public reaction to this particular White House scandal may also derive from the reality that e-mail is now an extraordinarily socialized technology. The peculiarities and idiosyncrasies of e-mail are well established in public discourse. Anyone who has ever used an e-mail program has accidentally deleted, misfiled, or otherwise misplaced an important message. Even though the number of emails lost by the White House is staggering, news of similar episodes is now almost commonplace. Indeed, the disappearance of e-mail in government or corporate spheres has become rather ordinary and "few days pass now without news about another major breach of data privacy, illegal destruction of data, or the inability to find historic data."95 Although one might anticipate that controversy involving a tool as popular and familiar as e-mail would pique the public interest, it seems that the opposite has in fact been the case. Paradoxically, the growth and spread of e-mail has seemingly made 
Americans less concerned about its abuse by corporate or government officials. Eight years ago it was estimated that Americans sent approximately 60 billion e-mails per year. ${ }^{96}$ By 2007 that number had reached almost 9 trillion. ${ }^{97}$ E-mail can now be sent, received, and deleted from a variety of portable devices. This convenience has contributed to the sheer volume of e-mail and also made communications technology an ever more integrated facet of American life. Indeed, modern society is characterized by "pervasive computing" $" 98$ resulting in an exponential increase in the creation and dissemination of digital material. Few people have noticed, or at least spent much time lamenting, the disappearance of the pay telephone in response to the evolution of cellular technology. It may be similarly difficult for people to be outraged by the loss of e-mail messages when such records are considered so ordinary and ephemeral.

Although the difficulties faced by the Bush White House might appear exceptional, this is certainly not the first administration to have difficulty preserving its own e-mail. In fact, every presidential administration that has used electronic mail since it was first installed in the White House during the early 1980's has lost, attempted to destroy, or somehow manipulated the resultant records. ${ }^{99}$ The Iran-contra scandal, for example, essentially revolved around the failed destruction of e-mail recording illegal and unconstitutional activity by some of President Reagan's closest advisors. The Reagan White House also attempted to erase e-mail backup tapes during its last week in office, an action that may have threatened up to 7 million records. ${ }^{100}$ The succeeding administration tried to keep control of its e-mail through a secret agreement with the Archivist of the United States, in clear violation of the Presidential Records Act. ${ }^{101}$ Such efforts even 
included enlisting government employees to cart off backup tapes in the hours shortly before the inauguration of the next president. ${ }^{102}$

The Clinton administration was forced via court order to adopt the Automated Records Management System (ARMS) during the mid-1990's. ${ }^{103}$ Even though ARMS featured preservation safeguards and automatic archiving, the Clinton administration still experienced trouble retaining e-mail. ${ }^{104}$ At one point, as many as two million messages sent by the Clinton White House were thought to have been lost or destroyed, ${ }^{105}$ though the majority of these records were eventually recovered. ${ }^{106}$ Despite some initial bugs, ARMS was known to be working effectively when the Bush administration took over in $2001 .^{107}$

There is a popular tendency in current-day political discourse to idealize the Clinton years as a period of relative enlightenment, particularly when compared to the cynical paranoia of the Bush era. However, it must be recognized that the Clinton White House, following precedent set by the Reagan and George H.W. Bush administrations, similarly argued that e-mail was not covered by federal legislation. ${ }^{108}$ The Clinton administration even attempted to place White House e-mail beyond the reach of Freedom of Information Act requests. ${ }^{109}$

What this suggests is that the attitude of presidential administrations toward email has less to do with party affiliation than with a desire to control information. E-mail was intended partly to replace White House telephone conversations that did not necessarily leave any record. ${ }^{110}$ The fear of committing official business to e-mail, which by law must be preserved, has had a dramatic impact on officials who fear that their words and actions may be misinterpreted. This is, in many ways, an understandable 
reaction and one that resonates within the public consciousness. We have all sent e-mails containing words, ideas, or sentiments that we would not want publicly broadcast or which removed from their proper context could be easily misconstrued. However, as the behavior of the Bush administration demonstrates, it is only a small step from trying to maintain discretion to deliberate evasion.

The fact that the power to form or control the historical record now lays in the hands of partisan White House functionaries should be a cause for serious alarm among the archival profession, whether the sitting administration is Republican or Democrat. It will not do to wait for public outcry to reach a crescendo before we respond. Archivists and records-managers can offer unique insight into this particular scandal since we have been grappling with the ethical challenges of electronic records, not to mention the records themselves, for decades.

In fact, the behavior of the Bush administration in this case would seem to represent a golden opportunity for archivists to publicly assert themselves. Yet, throughout the course of the controversy, there has been little apparent activity among the archival community. Although the website of the Society of American Archivists (SAA) is not entirely devoid of signs of political awareness, there is little acknowledgement of the e-mail scandal. ${ }^{111}$ Neither the International Council of Archivists (ICA) nor the Academy of Certified Archivists (ACA) appears to have taken much notice of the lost White House e-mail. ${ }^{112}$ Discussion of White House e-mail on the Archives and Archivist listserv has been sporadic, abbreviated, and mostly carried on by a few interested individuals. ${ }^{113}$ 
In contrast, the National Security Archive (NSA) has not only documented the scandal blow-by-blow, it has also taken direct action to counter the destruction of White House e-mail. ${ }^{114}$ Although the NSA performs some basic archival functions, it is not exactly part of the mainstream archival community. Its actions have, by and large, been conducted in conjunction with other whistleblower or watchdog groups and without the overt assistance of professional archival organizations. For the most part, the archival profession appears content to wait for its expertise to be recognized and its opinions solicited by society at large. But if archivists are to be effective advocates for the historical record, then they must be willing, if necessary, to raise their voices within ongoing social, cultural, and political discussions.

It is not unreasonable to expect archivists to assert themselves in the political sphere, since at various times in the past they have, in fact, demonstrated a willingness to act in defense of professional values. During the Reagan administration, the SAA was part of a diverse coalition of professional organizations that successfully lobbied Congress to remove the National Archives from the authority of the General Services Administration. ${ }^{115}$ The SAA later joined the American Historical Association and the Organization of American Historians in criticizing President Clinton's nominee to lead the National Archives and Records Administration. ${ }^{116}$ More recently, the SAA was included in an amici curiae brief filed as part of an appeal seeking to compel the current Vice President to disclose members of an energy policy task force. ${ }^{117}$

However, greater coordination and organization is necessary for sustained activity to be optimally effective. It seems unlikely that the SAA will soon be transformed into a politically dynamic organization. At present it may be more reasonable for American 
archivists to consider forming new groups designed for more explicitly political purposes. One interesting suggestion that has already been offered is the creation of an archival think-tank to facilitate professional research and discussion on certain vital issues. ${ }^{118}$ Such a body could form the intellectual foundation for lobbying state and federal officials, disseminating information needed to pursue a larger political agenda, and establishing common cause with other similarly minded organizations.

An archival think-tank would function, in essence, as an information clearinghouse for the profession, thereby helping to coordinate a unified and coherent response to crucial issues. The think-tank could in many ways emulate professional organizations such as the SAA while adhering to a more fundamentally political or advocacy-oriented agenda such as that followed by the NSA. Cooperation with groups such as the SAA, ACA, and ICA would be encouraged, though not considered a necessary requirement for action. Affiliation with a university would probably be helpful, as it has been for the NSA, but if necessary an "Institute for Information and Democracy, ${ }^{119}$ by whatever formal title, could also function as an independent professional organization. Although such a group would not be embraced by the entire archival community, it is an idea worthy of further exploration by those who see a need for greater socio-political action.

One final factor to consider as an explanation for the relatively muted popular reaction to the White House e-mail controversy is simply an overwhelming sense of scandal-fatigue. Compared to some of the other problems the Bush White House has generated, missing e-mail, no matter how voluminous, may just not register on the outrage meter. In addition, the e-mail scandal is a convoluted, complex, and far from 
glamorous tale. Despite its Nixonian overtones, there is no single villain to focus upon and, as yet, no "smoking C-drive" ${ }^{120}$ providing definitive evidence of wrongdoing.

In any event, legal and legislative efforts to hold the Bush Administration accountable for the loss or destruction of email have proved largely ineffective. While Congress has demonstrated a willingness to seek greater authority over White House communications, it is not clear if the political will exists to hold future members of the Executive branch accountable. ${ }^{121}$ Of equal importance, in June of 2008, a lawsuit filed by Citizens for Responsibility and Ethics in Washington under the Freedom of Information Act (FOIA) was dismissed in federal district court. ${ }^{122}$ The decision of the court constituted an endorsement of Bush Administration claims that the Office of Administration (OA) for the Executive Office of the President (EOP) does not qualify as a government agency and is therefore beyond the reach of the FOIA. This rather curious ruling was made despite the fact that the OA had not only been previously recognized but had explicitly identified itself as an agency of the EOP. ${ }^{123}$ Even though other pending lawsuits may produce decisions less favorable to the Bush Administration, it appears that many in the judicial and legal spheres have at least tacitly accepted White House insistence that the fundamental cause of the lost email lies with technological limitations rather than deliberate illegal activity. ${ }^{124}$

Although such excuses are both plausible and effective, archivists, recordsmanagers, and information technology professionals understand that it is not impossible to competently manage the email correspondence of an organization the size of the EOP. ${ }^{125}$ Unfortunately, the passage of time will most likely ensure that recovery of the lost White House email becomes increasingly difficult and that public interest in the 
matter will fade even beyond the current level of indifference. Nevertheless, there is no reason to assume that the historical narrative preferred by the Bush Administration must dominate future discussion of the years 2001-2008. If archivists truly subscribe to the ethical values articulated by professional organizations such as the SAA, then we will make certain that the historical legacy of the Bush Administration includes an explicit recognition of deliberate attempts to use the vagaries of information technology to hide or destroy vital records.

In the future, archivists must never tire of reminding the American people that the behavior of the Bush White House in regards to its own email is indicative of a fundamental hostility to the democratic ideals of government transparency and freedom of information. Indeed, the loss or destruction of e-mail is not an isolated instance but merely one piece of a comprehensive assault by the Bush White House on the ability of the American people to hold their government accountable. The current administration has consistently resisted compliance to open records laws, doing so only after exhausting every possible appeal and then often releasing material that is heavily redacted and essentially useless. ${ }^{126}$ George W. Bush has asserted executive privilege in order to undermine federal investigations and prevent members of his administration from testifying before Congress. ${ }^{127}$ The Bush administration has, in short, deliberately chosen to operate in secrecy and avoid contemporary accountability. Historians will similarly be unable to critically evaluate George W. Bush if he leaves no records intact or otherwise accessible. This hostility strikes at the very heart of the archival mission and requires an unequivocal and unambiguous professional response. 
Conclusion: Lessons and Themes. There are a variety of lessons emerging from these three cases, and in this conclusion we mention some worth considering (and we are sure there are others readers of this essay might also identify). Perhaps the most obvious point is that the very nature of what archivists used to think of as security, the nuts and bolts of protecting historical and other documentary sources in a fashion that still allows them to be used, is broadening. Now archivists must think of security as encompassing ethical and accountability issues as well, where the documentary heritage (real and potential) is under siege by the powers and principalities of the world. While archivists have worried that the technologies of recordkeeping will have undermined the creation and maintenance of information and documentary sources with continuing value to society, its institutions, and various disciplines needing these sources, it is also the case that there are challenges posed by the weak authority or will of archivists to withstand political, business, economic, and other agendas requiring the destruction (or noncreation) of records. A quarter-of-a-century ago Joan Hoff-Wilson, considering the value of professional ethics codes, suggested that these codes "can be compared to locking the barn door after the horse has escaped, since most are adopted after serious problems of standards have already developed within a profession." ${ }^{128}$ Archivists have continued to worry about their ethics, while supporting codes that are merely advisory and often vague, even as the challenges to these ethics have intensified. What is now at risk is the very security of a future documentary heritage, and this reminds us that the world is increasingly encroaching on what many attracted to the archival profession thought of as their quiet place to work in caring for archival and historical materials. 
Another powerful lesson, then, from cases such as these, might be the increasingly uncomfortable position archivists find themselves in. Even in the most seemingly benign of functions, such as assisting researchers to use the holdings of archival repositories, archivists find themselves in a labyrinth of conflicting laws, policies, and procedures. When Allison-Bunnell, more than a decade ago, reflected on the intellectual property issues of literary manuscripts, she concluded that the generally appropriate conservative actions of archivists could be questioned: "But if these conservative interpretations restrict researchers' access to valuable documents by preventing the limited and reasonable dissemination of those documents, the interpretations must be viewed with suspicion."129 In the short time that has passed such intellectual property concerns have become much more complicated and dangerous. Now, perhaps, archivists face an insecure future in their ability to perform even the most basic chores.

Given this, then, one might think that a new and more rigorous archival leadership would have emerged, but these cases suggest otherwise. Most archivists, if interviewed about the matter of professional leadership, would probably have a hard time identifying who and what comprises this leadership. Miller, two decades in his case study of the FBI threat to the control of archival sources, candidly stated, "if a similar case comes before the courts again the Society of American Archivists should not sit on the sidelines." 130 The evidence suggests, however, that not much has changed, although there have been occasional flashes by this professional association of stepping out to be a more vocal proponent in controversial archival issues. Perhaps, no one should be surprised by this. Herman Kahn, reviewing four decades ago the contentious charges of historian Francis 
Loewenheim, commenced his essay in this way: "It is appropriate to begin this discussion by reminding ourselves that libraries and archives are operated by human beings, not by angels." ${ }^{131}$ We have even more evidence today that this is the case. The issue remains, however, in how archivists re-invent their notion of professional ethics and accountability to form a new sense of archival security.

\section{Endnotes}

${ }^{1}$ Elena S. Danielson, "The Ethics of Access," American Archivist 52 (Winter 1989): 53.

${ }^{2}$ Harold L. Miller, "Will Access Restrictions Hold Up in Court? The FBI's Attempt to Use the Braden Papers at the State Historical Society of Wisconsin," American Archivist 52 (Spring 1989): 181.

${ }^{3}$ Ibid.

${ }^{4}$ Ibid., p. 189.

${ }^{5}$ Mark A. Greene, "Moderation in Everything, Access in Nothing?: Opinions About Access Restrictions on Private Papers,” Archival Issues 18, no. 1 (1993): 36.

${ }^{6}$ Jodi L. Allison-Bunnell, “Access in the Time of Salinger: Fair Use and the Papers of Katherine Anne Porter," American Archivist 58 (Summer 1995): 281.

${ }^{7}$ Lisa K. Speer, “Mississippi’s ‘Spy Files': The State Sovereignty Commission Records Controversy, 1977-1999," Provenance 17 (1999): 115.

${ }^{8}$ Ibid., p. 116.

${ }^{9}$ Douglas P. Lackey. "Ethics and Native American Reburials: A Philosopher's View of Two Decades of NAGPRA," in The Ethics of Archaeology: Philosophical Perspectives on Archaeological Practice, edited by Chris Scarre and Geoffrey Scarre (New York: Cambridge University Press, 2006), p. 146. 
${ }^{10}$ Joe Watkins. "Archaeological Ethics and American Indians," in Ethical Issues in Archaeology, edited by Larry J. Zimmerman, Karen D. Vitelli, and Julie HollowellZimmer. (Walnut Creek, CA: AltaMira Press, 2003), pp. 134-35.

${ }^{11}$ Northern Arizona University. Protocols for Native American Archival Materials, http://www2.nau.edu/libnap-p/index.html, accessed April 28, 2008.

${ }^{12}$ National Park Service, US Department of the Interior. "NAGPRA Frequently Asked Questions," National NAGPRA, http://www.nps.gov/history/nagpra/FAQ/INDEX.HTM, accessed April 28, 2008.

${ }^{13}$ James Riding in Cal Seciwa, Suzan Shown Harjo, and Walter Echo-Hawk, "Protecting Native American Human Remains, Burial Grounds, and Sacred Places: Panel

Discussion,” Wicazo Sa Review 19, no. 2 (2004): 170.

${ }^{14}$ Protocols. http://www2.nau.edu/libnap-p/protocols.html\#Culturally, accessed April 28, 2008.

${ }^{15}$ Ibid.

${ }^{16}$ Amy Cooper, "Issues in Native American Archives," Collection Management 27, no. 2 (2002): 45-46.

${ }^{17}$ Protocols. http://www2.nau.edu/libnap-p/protocols.html.

${ }^{18}$ Helen Freshwater, "The Allure of the Archive," Poetics Today 24, no. 4 (2003): 754.

${ }^{19}$ Protocols, http://www2.nau.edu/libnap-p/laws.html.

${ }^{20}$ Protocols, http://www2.nau.edu/libnap-p/index.html.

${ }^{21}$ Ruth Panofsky and Michael Moir, "Halted by the Archive: The Impact of Excessive Archival Restrictions on Scholars," Journal of Scholarly Publishing 37, no. 1 (2005): 30.

${ }^{22}$ Protocols. http://www2.nau.edu/libnap-p/protocols.html. 
${ }^{23}$ Protocols. http://www2.nau.edu/libnap-p/protocols.html\#Repatriation.

${ }^{24}$ Alexa Roberts, “Trust Me, I Work for the Government: Confidentiality and Public Access to Sensitive Information," American Indian Quarterly 25, no. 1 (2001): 15-16.

${ }^{25}$ Michael F. Brown, Who Owns Native Culture? (Cambridge, Massachusetts: Harvard University Press, 2003), p. 32.

${ }^{26}$ Clement Meighan, "Another View on Repatriation: Lost to the Public, Lost to History," Public Historian 14, no. 3 (1992): 43, 45.

${ }^{27}$ Protocols, http://www2.nau.edu/libnap-p/protocols.html\#Building.

${ }^{28}$ Protocols http://www2.nau.edu/libnap-p/index.html.

${ }^{29}$ Australian Library and Information Association, "The Aboriginal and Torres Strait Islander Protocols for Libraries, Archives and Information Services.” http://www1.aiatsis.gov.au/atsilirn/protocols.atsilirn.asn.au/index0c51.html?option=com_ frontpage\&Itemid=1, accessed April 28, 2008.

${ }^{30}$ The Society of American Archivists, "Charge: Task Force on Native American

Protocols Review (October 2007)," http://www.archivists.org/news/2007-

TFNatAmerProtocols-CHARGE.asp, accessed April 28, 2008.

${ }^{31}$ Verne Harris, “Archives, Politics and Justice," in Political Pressure and the Archival Record, ed. Margaret Proctor, Michael Cook, and Caroline Williams (Chicago, IL: The Society of American Archivists, 2005), p. 177.

${ }^{32}$ Ibid. As Harris indicates, the Dylan quote comes from his 1989 song, "Political World."

${ }^{33}$ See Charles F. Williams, "The United States Supreme Court and the World Wide Web," Social Education 66, no. 1 (2002), http://members.ncss.org/se/6601/660112.shtml 
for details on the difficulties found in any attempt to obtain Supreme Court transcripts and recordings before the wide availability and use of the World Wide Web. Williams also lists and reviews the various resources now available.

${ }^{34}$ Steve France, "A Penchant for Privacy: Court discourages advocates angling for openness," ABA Journal (December 1998): 38.

${ }^{35}$ Marjorie Cohn and David Dow, Cameras in the Courtroom: Television and the Pursuit of Justice (Jefferson, NC: McFarland, 1998), p. 121. The authors describe an incident where a "sidewalk entrepreneur" sold his place in line to hear the oral arguments of Webster v. Reproductive Health Services for one hundred dollars.

${ }^{36}$ For more on the Pentagon Papers controversy see John Prados and Margaret Pratt Porter, ed. Inside the Pentagon Papers (Lawrence, KS: University of Kansas Press, 2004).

${ }^{37}$ The wording of the agreement is quoted in, among others, Linda Greenhouse, "Justices Quash Entrepreneur's Move on the Court," The New York Times, September 26, 1993, http://www.nytimes.com.

${ }^{38}$ See Peter Irons, The Courage of Their Convictions (New York: Free Press, 1988).

${ }^{39}$ Preface to Peter Irons and Stephanie Guitton, ed., May It Please the Court: The Most Significant Oral Arguments Made Before the Supreme Court Since 1955 (New York: The New Press, 1993), p. viii.

${ }^{40}$ Peter Irons, Statement to United States Senate Committee on the Judiciary, Cameras in the Courtroom, Senate Hearing 109-331, November 9, 2005 (Washington, D.C.: U.S. Government Printing Office, 2006), p. 93. 
${ }^{41}$ Ibid. No stranger to resistance, Irons had previously served a 26 month federal prison sentence (and was much later pardoned by President Gerald Ford) for refusing to carry a draft card in 1961. See Gary Seidman, "Out of the Irons, Into the Docks," The Harvard Crimson, December 12, 1975, http://www.thecrimson.com/article.aspx?ref=107769 and Gary Seidman, "Law Student Gets Presidential Pardon: Ford Clears Draft Resistor," January 31, 1977, http://www.thecrimson.com/article.aspx?ref=151004.

${ }^{42}$ Robb Jones quoted in Henry J. Reske, "Publicity-Shy Justices Criticize Prof,” $A B A$ Journal (November 1993): 36. See also Joan Biskupic, "Marketer of Court Tapes Risks Supreme Court Censure," The Washington Post, August 30, 1993, http://www.lexisnexis.com.

${ }^{43}$ Toni House quoted in William Safire, "Essay: Court's Greatest Hits," The New York Times, August 19, 1993, http://www.nytimes.com.

${ }^{44}$ Charles P. Fried quoted in Sarah Lyall, "Book Notes," The New York Times, September 8, 1993, http://www.nytimes.com.

${ }^{45}$ The New York Times, “The Sound of Nine Justices Flapping,” September 17, 1993, http://www.nytimes.com. Irons responded to the complaints about his work with a letter to the editor. See Peter Irons, "High Court Tapes Open a Window on History in the Making," The New York Times, October 12, 1993, http://www.nytimes.com. ${ }^{46}$ The Washington Post, "The Supreme Court on Tape,” August 24, 1993, http://www.lexisnexis.com.

${ }^{47}$ From their discovery in the 1950 s until 1991, the Dead Sea Scrolls were only available to a select group of scholars. In 1991, the Huntington Library took on the Israeli Antiquities Authority and announced they were allowing unrestricted access to 
photographs they held of the scrolls. For a detailed discussion of the controversy and the ethics of unequal access see Sara S. Hodson, "Freeing the Dead Sea Scrolls: A Question of Access," American Archivist 56 (Fall 1993): 690-703. See also Barbara Case and Ying Xu, “Access to Special Collections in the Humanities: Who's Guarding the Gates and Why?" The Reference Librarian no. 47 (1994): 129-146.

${ }^{48}$ Safire, "Essay: Court's Greatest Hits."

${ }^{49}$ Joan Biskupic, "Supreme Court Limits Access by Seller of Tapes," The Washington Post, September 24, 1993, http://www.lexisnexis.com.

${ }^{50}$ Joan Biskupic, “Court Makes Tapes of Arguments Available," The Washington Post, November 2, 1993, http://www.lexisnexis.com. See also Linda Greenhouse, "Supreme Court Eases Restrictions on Use of Tapes of Its Arguments," The New York Times, November 3, 1993, http://www.nytimes.com.

${ }^{51}$ See Peter Irons and Stephanie Guitton, ed., May It Please the Court: Arguments on Abortion (New York: The New Press, 1995); Peter Irons, ed., May It Please the Court: The First Amendment (New York: The New Press, 1997); and Peter Irons, ed., May It Please the Court: Courts, Kids, and the Constitution (New York: The New Press, 2000). 52 The Supreme Court's secrecy and mystique as a group of just nine, self-regulating, lifetime appointees is discussed at length in sources too numerous to adequately summarize here. The following recent and/or influential treatments were consulted in preparation for this paper: Dahlia Lithwick, "Justice Confidential," American Lawyer 25, no. 9 (September 2003), http://find.galegroup.com/itx/start.do?prodId=EAIM; Lawrence S. Wrightman, The Psychology of the Supreme Court (New York: Oxford University Press, 2006); Jeffrey Toobin, The Nine: Inside the Secret World of the Supreme Court 
(New York: Doubleday, 2007); and Bob Woodward and Scott Armstrong, The Brethren: Inside the Supreme Court (New York: Simon and Schuster, 1979).

${ }^{53}$ Irons, Statement to United States Senate Committee on the Judiciary, Cameras in the Courtroom, p. 93.

${ }^{54}$ Yet even in the case of private donors, the appropriateness and legality of access restrictions have come up for debate. See, among others, Elena S. Danielson, “The Ethics of Access," American Archivist 52 (Winter 1989): 52-62; Sara S. Hodson, "Private Lives: Confidentiality in Manuscripts Collections," Rare Books \& Manuscripts Librarianship 6, no. 2 (1991): 108-118; Menzi L. Behrnd-Klodt and Peter J. Wosh, ed. Privacy \& Confidentiality Perspectives: Archivists and Archival Records (Chicago, IL: The Society of American Archivists, 2005); Mark A. Greene, "Moderation in Everything, Access in Nothing?"; Marybeth Gaudette, "Playing Fair With the Right to Privacy," Archival Issues 28, no. 1 (2003/2004): 21-34; Joseph L. Sax, Playing Darts with a Rembrandt: Public and Private Rights in Cultural Treasures (Ann Arbor, MI: University of Michigan Press, 1999); and Harold L. Miller, "Will Access Restrictions Hold Up in Court?"

${ }^{55}$ Helpful discussions of the ethics of access to archival materials can be found in Elena S. Danielson, "Ethics and Reference Services," The Reference Librarian no. 56 (1997): 107-124 as well as Mary Jo Pugh's chapter on "Determining Access Policies" in her manual Providing Reference Services for Archives \& Manuscripts (Chicago, IL: The Society of American Archivists, 2005). 
${ }^{56}$ See David Johnston, "Marshall Papers Reveal Court Behind the Scenes," The New York Times, May 24, 1993, http://www.nytimes.com; Neil A. Lewis, “Chief Justice Assails Library on Release of Marshall Papers," The New York Times, May 26, 1993,

${ }^{57}$ William H. Rehnquist, “... and Rehnquist's Protest,” The New York Times, May 26, 1993, http://www.nytimes.com.

${ }^{58}$ Neil A. Lewis, “Librarian Vows to Continue Public Access to Marshall's Papers," The New York Times, May 27, 1993, http://www.nytimes.com.

59 James H. Billington's May $26^{\text {th }}$ statement is reprinted in its entirety in Barbara Bryant, “Thurgood Marshall Collection: Press Stories Stir Furor Over LC’s Opening of Papers,” The Library of Congress Information Bulletin 52, no. 12 (June 14, 1993), http://www.loc.gov/loc/lcib/93/9312/marshall.html.

${ }^{60}$ John N. Berry III, “It's a Question of Open Government," Library Journal 118, no. 11 (June 15, 1993): 8.

${ }^{61}$ ALA Council, "Resolution on Access to Justice Thurgood Marshall's Papers at the Library of Congress," June 30, 1993, reprinted in Newsletter on Intellectual Freedom 42 (September 1993): 166.

${ }^{62}$ Richard J. Cox and David A. Wallace, "Introduction," in Archives and the Public Good: Accountability and Records in Modern Society, ed. Richard J. Cox and David A. Wallace (Westport, CT: Quorum Books, 2002), p. 8.

${ }^{63}$ Ted Gup, Nation of Secrets: The Threat to Democracy and the American Way of Life (New York: Doubleday, 2007), p. 25.

${ }^{64}$ Harris, “Archives, Politics and Justice,” p. 182. 
${ }^{65}$ Evidence can be found on the Archives and Archivist listserv at WwW .forums .archivists .org/read/?forum=archives.

${ }^{66}$ Jason Leopold, "Investigators Eye Broader White House Email Trail,” truthout, 05 April, 2007, <.http://www.truthout.org/docs_2006/040507J.shtml> (25 January 2008). See also "White House Admits No Back-Up Tapes for E-Mail Before October 2003," National Security Archive, 16 January 2008, $<$ http://www.gwu.edu/ nsarchiv/news/20080116/index.htm> (25 January 2008).

${ }^{67}$ Ben Bain, "White House Discloses Details of E-mail Backup System,” Federal Computer Week, 16 January, 2008, < http://www.fcw.com/online/news/151320-1.html> (25 January 2008). See also Daniel Schulman, “The Emails the White House Doesn’t Want You to See," Mother Jones, 30 March 2007, $<$ http://www.motherjones.com/washington_dispatch/2007/03/white_house_emails.html $>$ (23 February 2008). See also “Well, We Found 140,000,” New York Times, 20 June 2007, $<$ http://www.nytimes.com/2007/06/20/opinion/20wed2.html?_r=1\&scp=1\&sq=\%22Well $\% 2 \mathrm{C}+\mathrm{We}+$ Found $\% 22 \&$ st=nyt\&oref $=$ slogin $>(16$ February 2008$)$.

${ }^{68}$ Schulman, “The Emails the White House Doesn't Want You to See." ${ }^{69}$ John Oates, “Investigators Find Secret White House Email Accounts, The Register, 19 June 2007, <http://www.theregister.co.uk/2007/06/19/whitehouse_cogr_emails/> (23 February 2008). The actions of the Bush White House may also have violated the Federal Records Act. See James D. Lewis, "White House Electronic Mail and Federal Recordkeeping Law: Press 'D' to Delete History," Michigan Law Review 93, No. 4 (February 1995), 795. 
${ }^{70}$ Schulman, “The Emails the White House Doesn't Want You to See.” Contrary to early claims by the Bush administration, it was eventually learned that the White House began using RNC e-mail accounts in 2001. See “They”ve got mail: Congress Should Be Able to See E-mail About Official Business, No Matter Which Account it Was Sent From," Los Angeles Times, 11 April 2007, p. A22. Some indication that the White House was not preserving e-mail properly emerged in early 2006 during the Scooter Libby investigation. See Leopold, "Investigators Eye Broader White House Email Trail.”

${ }^{71}$ This interpretation is simply wrong. Use of the RNC accounts for official government business clearly violates federal records legislation. See Schulman, "The Emails the White House Doesn't Want You to See.”

${ }^{72}$ Los Angeles Times, “They’ve Got Mail.”

${ }^{73}$ Leopold, "Investigators Eye Broader White House Email Trail.” The use of RNC accounts bolstered suspicions that the firings were politically motivated, a contention denied by the Bush administration.

${ }^{74}$ Daniel Schulman, "More Answers in the Missing Email Caper," Mother Jones, 26 February 2008, <.http://www.motherjones.com/mojoblog/archives/2008/02/7347_more_answers_in.html $>$ (27 February 2008).

${ }^{75}$ Dan Eggen, “GOP Halts Effort To Retrieve White House E-Mails," Washington Post, 27 February 2008, <http://www.washingtonpost.com/wpdyn/content/article/2008/02/26/AR2008022602312.html> (27 February 2008). In addition to not having a functioning archival system, the networks used by the RNC were open and unsecured, a fact that should have alarmed an administration so consumed with 
national security. See Robin Harris, “Tech Idiocy in the White House," ZDNet, 5

February 2008, <http://blogs.zdnet.com/storage/?p=286> (9 February 2008).

${ }^{76}$ Leopold, "Investigators Eye Broader White House Email Trail.”

${ }^{77}$ Paul Kiel, "White House Says Emails Lost Due to Tech Glitch,” TPM Muckracker, 13 April 2007, $<$ http://tpmmuckraker.talkingpointsmemo.com/2007/04/white_house_says_emails_lost_d .php $>$ (25 January 2008). See also Nick Bauman, “White House 'Recycled’ Backups of its Email Records,” Mother Jones, 16 January 2008, $<$ http://www.motherjones.com/mojoblog/archives/2008/01/6883_white_house_doe.html $>$ (25 January 2008).

${ }^{78}$ Michael Weisskopf, "Where Are the White House E-mails?,” TIME, 23 January 2008, $<$ http://www.time.com/time/nation/article/0,8599,1706374,00.html> (25 January 2008) See also National Security Archive, "White House Must Answer Questions About Missing Emails, Magistrate Judge Rules,” 8 January, 2008, $<$ http://www.gwu.edu/ nsarchiv/news/20080108/index.htm> (25 January 2008). See also Elizabeth Williamson and Dan Eggen, "White House Has No Comprehensive E-mail Archive; System Used by Clinton Was Scrapped," Washington Post, 22 January 2008,< http://www.washingtonpost.com/wpdyn/content/article/2008/01/21/AR2008012102070_pf.html> (16 February 2008). ${ }^{79}$ Paul Kiel, "White House Says Emails Lost Due to Tech Glitch,” TPM Muckracker, 13 April 2007, <http://tpmmuckraker.talkingpointsmemo.com/2007/04/white_house_says_emails_lost_d .php> (25 January 2008). See also Bain, "White House Discloses Details of E-mail 
Backup System.” Some reports identified the new program as Microsoft Exchange. See Bain, "White House Discloses Details of E-mail Backup System.”

${ }^{80}$ Bauman, "White House 'Recycled' Backups of its Email Records," 16 January 2008, <http://www.motherjones.com/mojoblog/archives/2008/01/6883_white_house_doe.html> (25 January 2008).

${ }^{81}$ Chris Maxcer, "White House Admits Recycling Tapes, Hedges on Missing E-mail," Tech News World, 18 January, 2008, < http://www.ecommercetimes.com/story/61276.html> (25 January 2008). ${ }^{82}$ Weisskopf, "Where Are the White House E-mails?" The National Archives and Records Administration began warning the White House about its poor recordsmanagement practices as early as January 2004, but the Bush administration ignored its advice. See National Security Archive, "White House Ignored Repeated Warnings That E-mails Were At Risk,” 26 February 2008, <http://www.gwu.edu/ nsarchiv/news/20080226/index.htm> (27 February 2008).

${ }^{83}$ Dan Eggen and Elizabeth Williamson, "White House Study Found 473 Days of E-Mail Gone," Washington Post, 18 January, 2008, <http://www.washingtonpost.com/wpdyn/content/story/2008/01/18/ST2008011802092.html> (25 January 2008).

${ }^{84}$ Bain, "White House Discloses Details of E-mail Backup System." ${ }^{85}$ Eggen and Williamson, "White House Study Found 473 Days of E-Mail Gone." ${ }^{86}$ Weisskopf, "Where Are the White House E-mails?" See also Pete Yost, "Still No Upgrade for White House E-Mail,”'Associated Press, 25 February 2008, $<$.http://ap.google.com/article/ALeqM5hKKWSY_43nHexg55YcW2X9YXNayAD8V1L NGO0> (28 February 2008). 
${ }^{87}$ National Security Archive, "White House Ignored Repeated Warnings That E-mails Were At Risk,” 26 February 2008, <http://www.gwu.edu/ nsarchiv/news/20080226/index.htm> (27 February 2008).

${ }^{88}$ Eggen and Williamson, "White House Study Found 473 Days of E-Mail Gone.”

${ }^{89}$ Associated Press, "White House Data Recycling May Have Caused Email Loss," Wall Street Journal, 16 January 2008.

<http://online.wsj.com/article/SB120053640318296431.html?mod=googlenews_wsj> (25 January 2008).

${ }^{90}$ Pete Yost, "Still No Upgrade for White House E-Mail." See also Sylvie Barak, "Whitehouse "lost” Email Scandal Gains Traction,” The Inquirer, 26 February 2008, $<$ http://www.theinquirer.net/gb/inquirer/news/2008/02/26/whitehouse-lost-emailscandal> (27 February 2008).

${ }^{91}$ Barak, "Whitehouse "lost" Email Scandal Gains Traction."

${ }^{92}$ Schulman, "More Answers in the Missing Email Caper."

${ }^{93}$ New York Times, “None Dare Call It Nixonian: The White House (Apparently) Lost a Bit of E-Mail," 5 February 2008, <.http://theboard.blogs.nytimes.com/2008/02/05/nonedare-call-it-nixonian-the-white-house-apparently-lost-a-bit-of-email/> (9 February 2008). ${ }^{94}$ Eggen, "GOP Halts Effort to Retrieve White House E-Mails."

${ }^{95}$ Alan Pelz-Sharpe, “The Grim Realities of Content Security,” Intelligent Enterprise, 25 January 2008, $<$ http://www.intelligententerprise.com/blog/archives/2008/01/the_grim_realit.html;jsessi onid=YDYQGATA3TH2SQSNDLPCKHSCJUNN2JVN> ( 26 January 2008). 
${ }^{96}$ Clay Redding, "Preservation of E-mail Addressed by New Studies," American Institute of Physics, AIP History Newsletter 32, No 2 (Fall 2000), <http://www.aip.org/history/newsletter/fall2000/email.htm> (6 March 2008).

${ }^{97}$ James Risen, State of War: The Secret History of the CIA and the Bush Administration (New York: Free Press, 2007), p. 48.

${ }^{98}$ Bryan Bergeron, Dark Ages II: When the Digital Data Die (Upper Saddle River, NJ: Prentice Hall PTR, 2001), p. 194.

${ }^{99}$ Tom Blanton ed., White House E-Mail: The Top Secret Computer Messages the Reagan/Bush White House Tried to Destroy (New York: The New Press, 1995), 5. The first White House e-mail system installed in 1982 was a prototype mainly for use by the Reagan Cabinet. E-mail was fully implemented in the White House by 1986.

${ }^{100}$ Ibid., pp. 2, 5.

${ }^{101}$ Ibid., 2, 10.

${ }^{102}$ Ibid., 9-10.

${ }^{103}$ Richard Koman, "Bush Deleted Email Archive System, Recycled Backup Tapes," ZDNet, 22 January 2008, <http://government.zdnet.com/?p=3618> (25 January 2008). ${ }^{104}$ Ibid.

${ }^{105}$ Elizabeth Williamson and Dan Eggen, "White House Has No Comprehensive E-Mail Archive; System Used by Clinton Was Scrapped,” Washington Post, 22 January 2008, $<$.http://www.washingtonpost.com/wpdyn/content/article/2008/01/21/AR2008012102070.html> (16 February 2008). ${ }^{106}$ Anonymous, "Those Missing E-Mails; Not as Bad As You Think, Not As Good As it Should Be," Washington Post, 11 February 2008, A12. 
${ }^{107}$ Ibid.

${ }^{108}$ Blanton, pp. 2, 10.

${ }^{109}$ Ibid., p. 2.

${ }^{110}$ Ibid., p. 21.

111 The only explicit mention of the e-mail scandal found is through a link to a column by Maureen Dowd which portrays archivists in a humorous but positive light. See

“Archivists Are 'New Macho Heroes of Washington"” at www.archivists.org/index.asp.

${ }^{112}$ See www.certifiedarchivists.org/index.html. See also www.ica.org.

${ }^{113}$ See Archives and Archivist listserv < forums.archivists.org/read/?forum=archives $>$.

${ }^{114}$ See National Security Archive, www.gwu.edu/ nsarchiv.

115 Paige Putnam Miller, “Archival Issues and Problems: The Central Role of Advocacy," The Public Historian 8, No. 3 (Summer 1986): 60.

${ }^{116}$ Scott Armstrong, “The War Over Secrecy: Democracy's Most Important LowIntensity Conflict," in A Culture of Secrecy: The Government Versus the People's Right to Know, ed. Athan G. Theoharis (Lawrence, KS: University of Kansas Press, 1998), pp. $157-8$.

${ }^{117}$ National Security Archive, "National Security Archive Joins Library and Public Interest Groups Supporting Public Access to Special Interests Participating in Cheney's Energy Task Force,” 30 November 2004, <http://www.gwu.edu/ nsarchiv/news/20041130/index.htm> (15 March 2008).

${ }^{118}$ Thomas James Connors, "The Bush Administration and 'Information Lockdown,” in Political Pressure and the Archival Record, eds., Michael G. Cook, Margaret Procter and Caroline Williams (Chicago: Society of American Archivists, 2005), p. 208. 
${ }^{119}$ Ibid.

${ }^{120}$ New York Times, "Well We Found 140,000."

${ }^{121}$ Jim Abrams, “House OKs Tighter Controls over White House E-mail,” BNet, 10 July 2008, <http://findarticles.com/p/articles/mi_qn4188/is_/ai_n27923211>,(23 September 2008).

${ }^{122}$ Kevin Fayle, "Info on Missing White House Emails to Remain Missing," The Register, 16 June 2008, <http://www.theregister.co.uk/2008/06/16/foia_white_house_emails/> (20 September 2008).

${ }^{123}$ Ibid.

${ }^{124}$ Jason Leopold, “IBM, Darrell Issa, and Millions of "Lost” White House Emails," OpEd News, 11 May 2008, $<$ http://www.opednews.com/articles/genera_jason_le_080325_ibm_2c_darrell_issa_2c_a $. h t m>(13$ May 2008).

${ }^{125}$ Mary Jander, "Suppliers Suggest White House Email Fixes,” Byte and Switch 1 May 2008 , $<\mathrm{http}: / /$ www.byteandswitch.com/document.asp?doc_id=152687\&WT.svl=news2_2>,(13 May 2008).

${ }^{126}$ Bruce P. Montgomery, Subverting Open Government: White House Materials and Executive Branch Politics (Lanham, MD: The Scarecrow Press, 2006), pp. 171-2.

${ }^{127}$ Reynolds Holding “The Executive Privilege Showdown,” TIME, 21 March 2007, <http://www.time.com/time/nation/article/0,8599,1601450,00.html> (15 March 2008). 
${ }^{128}$ Joan Hoff-Wilson, “Access to Restricted Collections: The Responsibility of Professional Historical Organizations," American Archivist 46 (Fall 1983): 442.

${ }^{129}$ Allison-Bunnell, “Access in the Time of Salinger,” p. 282.

${ }^{130}$ Miller, “Will Access Restrictions Hold Up in Court?”, p. 189.

${ }^{131}$ Herman Kahn, “The Long-Range Implications for Historians and Archivists of the Charges Against the Franklin D. Roosevelt Library," American Archivist 34 (July 1971): 265). 